\title{
Worshipful Gentlemen of England: The Studio of Padua and the Education of the English Gentry in the Sixteenth Century*
}

\author{
KENNETH R. BARTLETT
}

There had been an English nation at the University of Padua from its foundation in 1222. Throughout the Middle Ages, Englishmen had journeyed to that city to study in every discipline - Arts, Law, Medicine, Theology and usually returned home to enrich the intellectual life of their native country. Moreover, by the fifteenth century there had developed an additional impetus to study in Italy: the opportunity to learn Greek. Padua established a chair in that language in 1463; and its first incumbent, the Byzantine, Demetrius Chalcondyles, began the tradition of Paduan pre-eminence in Greek Studies. ${ }^{1}$

It was the attraction of this new humanist discipline of Greek, together with the ancient tradition of English study at Padua, a tradition reinforced by the close and harmonious relations between England and the Venetian Republic in whose terrafirm territories the university lay, that sustained the connection between the scholarly communities. Englishmen travelled to Padua in significant numbers; and those who made the journey often returned infected with enthusiasm for the New Learning taught in Italy, and subsequently spread the contagion to their fellow countrymen from the positions of influence that their special education earned for them.

For example, William Grocyn, who studied in Padua with Chalcondyles from 1488-1490, was the first Englishman to teach Greek in England (14911496). And, later this Grocyn became the tutor of William Lily, who was named by John Colet (himself a visitor to Italy) as the first master of his new school at St. Paul's; thus, a close connection was established between the studio of Padua in the fifteenth century and English humanist education in the sixteenth.

This relationship was reinforced by other important English scholars who migrated to Padua. Thomas Linacre left Oxford in 1487 to study Greek with Chalcondyles at Florence, but later moved to Padua where he took his M.D. in

*A version of this paper was delivered to the Canadian Society for Renaissance Studies at the Learned Societies Meeting in Halifax, Nova Scotia, on 22 May 1981. 
1496. While there he made the acquaintance of Niccolò Leonico Tomeo ${ }^{2}$ who was then lecturing on the Greek text of Aristotle, and of the Venetian printer Aldus Manutius for whom he prepared an edition of Proclus' De sphera (1499). Two years after Linacre's M.D., William Latimer was in Padua where he, too, established a friendship with Leonico which continued even after the Englishman had returned to Oxford. This continued connection led to Latimer's recommendation of Reginald Pole, his pupil at Magdalen and a cousin of Henry VIII, to Leonico in Padua for futher studies in Greek.

The place of Padua, then, in the decades before 1521 was central for English scholars. The previous waves of English educational travellers earlier in the fifteenth century - which included such luminaries as Tiptoft, Flemyng, Gunthorpe and Neville ${ }^{3}$ - produced no extensive, self-perpetuating tradition of scholarly relations between England and Italy except for the nourishment of humanist libraries. ${ }^{4}$ However, the last generation of that century, led by Linacre, Grocyn and Latimer, began a new continuous association between the two nations. Italy, especially the University of Padua, became almost the graduate school of English humanism, a place to which eminent scholars sent their most promising students to further their knowledge in those fields still not adequately served by the established curricula of Oxford and Cambridge.

The War of the League of Cambrai (1509-1510) was almost a fatal disaster for the studio, as it was for all things Venetian. The university was closed in 1509 , and Padua was taken by the enemy and the scholars dispersed. Once the peace was settled, it took several years to rebuild the university to its former state. By 1517 the students had begun to return, and by the early 1520's the reputation of the studio had been restored. Indeed, for the next half-century Padua surpassed its already formidable fame and was accounted the most prestigious seat of learning in Europe.

It was the Republic's policy of freedom and innovative scholarship that rebuilt the university's reputation and refilled the depleted halls of the $B \dot{o}^{5}$ after the crisis of the war. The remarkable climate of intellectual investigation and lack of external restraints gave reality to the university's motto, universa universis Patavina libertas. The faculties were subject more to the Venetian state than to the archbishop of Padua, and the cosmopolitan atmosphere drew students of various backgrounds, nationalities and even religious beliefs. ${ }^{6}$ The Venetians treated heresy as a political matter, ${ }^{7}$ and were loathe to act in any that would affect negatively the newly restored reputation of the University of Padua.

Every effort was made not only to ensure a favourable climate for scholarship but also to embellish both the facilities and the staff of this studium venetum which had almost become a symbol of Venetian recovery and renewed glory in the face of Europe. The Fleming, Vesalius, began his medical lectures at Padua in 1537. In 1540 the famous lectura criminalium was established in the Law Faculty after a successful petition from the 
students. Altogether, the teaching of the law was directed away from the detailed study of sources and abstract ideas towards the practice of law, illuminated through philological and historical understanding: the law became a discipline of humanism. Giovanni Battista de Monte (Montanus) originated his medical clinic in 1543; and two years after, the great Botanical Garden, the first in Europe, was laid out. There could have been no doubt but that Venice and her university had regained, if not surpassed, the old image of her pre-eminence in Italy.

Moreover, Venice had become in some ways the last major "Italian" state. Naples and Milan were provinces of Spain, and Florence was so close a dependent that her independence was illusory. The Papal states had yet to recover from the Lutheran revolt and the humiliation of the sack of Rome (1527). Thus, for anyone who wished an excellent humanistic, legal or medical education in a country not under Hapsburg control, the best choice was Padua. Consequently, the Serenissima, although realistically circumspect after her defeat at Agnadello, was cast by default into the role of guardian of Italian liberty and chief antagonist of the Hapsburgs in Italy. Given this, Padua represented not only the vitality of the Republic's civilization but was also a refuge for students from all over Europe, including Protestants, who were hostile to the Hapsburg hegemony. ${ }^{8}$

This was the environment in which the next generation of English students at Padua found themselves. There had been, of course, one fallow period the duration of the War of the League of Cambrai - in which no Englishmen had made the journey to Venice to study. Nevertheless, the links with the earlier generation, that of Grocyn, Latimer and Linacre, remained unbroken.

Reginald Pole was twenty-one years old when he first arrived in Padua in April of 1521. A cousin of Henry VIII, he had been educated at the Charterhouse of Sheen (so closely associated with Colet) and by the Carmelites at Oxford. He matriculated at Magdalen College, Oxford, where his tutor had been William Latimer. At his own request Pole was allowed to travel to Italy to study humanities with Latimer's old teacher, Leonico, and was granted a comfortable pension by the King to support his rank while abroad.

Within a short time, Pole's large and luxurious house in Padua had become a centre for foreign - especially English - students resident at the university. ${ }^{9}$ For example, in 1552, Thomas Lupset, friend of Erasmus and former lecturer in rhetoric at Wolsey's grandiose Cardinal College, arrived in Padua. Lupset, together with Pole, Dr. John Clement (More's son-in-law) and Dr. Edward Wotton (M.D. Padua 1525) worked jointly on a Greek text of Galen which was to be printed by Aldus in Venice. This enterprise, completed in 1524, had been inspired by Linacre and Leonico - indeed, the original idea may have been the Italian's - and illustrated the Paduan tendency to combine Greek with medical studies.

Such a vital climate of intellectual activity was appreciated in England. 
Thomas Winter (Cardinal Wolsey's natural son) wrote to Cromwell from Padua: "There are professors of all sciences here such as [I have] never hitherto heard, philosophers into whom the mind of Aristotle seems to have migrated, and civil lawyers and physicians than whom there are none more learned." ${ }^{10}$ Rather than rhetorical hyberbole, Winter's description was received as an accurate observation. ${ }^{11}$

Pole, too, after a six year absence from Italy (1526-1532) returned to the university to continue the studies he had begun there. Affected deeply by the events of the divorce of his cousin, the King, he withdrew from the employments thrust upon him during his absence and re-entered the scholarly atmosphere of the studio. Although his circle had been irrevocably reduced by the death of Leonico (1531), Pole returned to Padua in the role of patron and senior scholar in his own right. Fortified by a considerable royal pension, the English nobleman continued to use his household as an unofficial English "graduate" college in Padua, attracting to it a new generation of humanists.

W.G. Zeeveld has shown this period of Pole's second residence in Padua to have been one of the most fertile episodes in the entire history of EnglishItalian intellectual relations. The scholars who joined Pole's household in Italy were later either to return to England as official publicists, ambassadors and lawyers in the service of the Henrician Reformation, or to remain with Pole to become the spokesmen for continued English communion with Rome. Regardless of the nature of their choice, the substance of their education and activities at the studio represented perhaps the most significant element in their scholarly experience. ${ }^{12}$

Moreover, the increasing role of Padua as a place of higher education during the 1530's owed as much to the general political and intellectual climate in England as to the convenient situation of a great English aristocratic household in that city. In 1529, Cardinal Wolsey had fallen from royal favour and had died soon after. With him ended the rich and luxuriant growth of his special foundation, Cardinal College, Oxford. Those scholars whom he had lured from other colleges or whom he had supported through the foundation consequently found themselves without sufficient patronage or employment in England commensurate with their earlier expectations.

Hopes for a new source of patronage were subsequently focused on the household of Reginald Pole. His great wealth, expectations and reputation drew to him many scholars who hoped to replace Wolsey's patronage with Pole's while still enjoying access to an excellent humanistic education. His rank and fame would give his associates an entrée into any library or circle they desired, and his contacts might provide hope of some responsible office in which a scholar might apply his humanistic principles to the service of the state. No college at either English university - with the possible exception of Bishop Fox's new foundation of Corpus Christi College, Oxford - could offer as broad a background in litterae humaniores as Wolsey's had promised; and, 
for those displaced scholars of Cardinal College who had adopted reformed beliefs, the prospect of the religious toleration of the Venetian Republic provided an added incentive to journey to the studio. ${ }^{13}$ Consequently, a number of English students, all of whom had had some university experience in England, travelled to Padua after 1532 to enrol as scholars and share Pole's liberality.

For example, Thomas Starkey ${ }^{14}$ had been a student at Magdalen College, Oxford (M.A. 1521), as had Pole. Attracted to Cardinal College by Wolsey, he migrated there even though he had procured a fellowship at Magdalen in 1524. The fall of Wolsey in 1529 drove Starkey to seek a new patron in the person of Reginald Pole. He served as Pole's secretary during his mission to France (1529) to obtain the opinion of the Sorbonne on the matter of the King's divorce, and was granted in 1530 the income of a benefice formerly held by Thomas Lupset.

Following Pole to Padua, Starkey entered the studio as a legist and resided in his patron's house from 1532. Receiving his D.C.L. in 1534, he wrote an unsolicited opinion to Cromwell concerning the royal divorce. Cromwell took an interest in the young civilian and invited him to return to England to serve the King. Thereafter, Starkey was employed as an apologist for the Henrician Reformation, writing such pieces as the propagandistic An Exhortation to the People Instructing Them to Unity and Obedience ${ }^{15}$ and the abstract, humanistic Dialogue Between Pole and Lupset. ${ }^{16}$

Starkey's fellow, Richard Morison, had an even more successful career. After receiving his B.A. from Cardinal College in 1528, Morison moved to Padua where he entered the household of Reginald Pole and the Law Faculty of the university. He was elected Consiliarius of the English nation the following year, ${ }^{17}$ and simultaneously was deeply engaged in the study of both Greek and Italian. ${ }^{18}$

Like Starkey, Morison wrote to Cromwell asking for employment. His request was granted in 1536 and the young scholar returned home to establish a very successful reputation - and a great fortune - as a publicist and lawyer under Henry VIII and as an ambassador and courtier under Edward VI.

Other members of Pole's household remained consistently loyal to Rome. For example, George Lily, son of the William Lily who had been the fellow student of Grocyn and Linacre in Italy and Colet's first master of St. Paul's School, had studied at Magdalen College, Oxford, as had Pole and Starkey. About 1532, Lily joined Pole in Padua, becoming his intimate and confidant, and remained in Italy with Pole after his rupture with Henry VIII, returning to England only when Queen Mary elevated her cousin to the See of Canterbury.

Thomas Goldwell ${ }^{19}$ was similarly an English Catholic who chose residence in Italy with Pole over any accommodation with the Henrician Reformation. Like Lily, Goldwell accompanied the Cardinal to England in 1554 where he was rewarded for his fidelity with a bishopric. 
Henry Cole, ${ }^{20}$ a sometime friend of Morison, received his B.C.L. at Oxford. A serious student of Civil Law, Cole was resident in Padua from 1530, two years before Pole arrived on his second visit. Once that nobleman had established his household in Padua, however, Cole became an habitue of it and, indeed, remained there until 1537, a year after his patron had departed for Venice, leaving him as the last English associate of Pole still resident at the university after the dissolution of his familia.

The English Catholics who chose to remain in Italy after 1536, either as members of Reginald Pole's entourage or as individuals, had little influence on subsequent generations of English students in Italy. Indeed, their example made the danger of "going to Pole" 21 all the more apparent to Protestant observers. Nevertheless, they did illustrate how Venice functioned as a refuge for English dissenters who were awaiting changes in the political or religious order at home. In their case, once those reversals of policy were effected, they returned to England and found places of honour at the court of Queen Mary, only to have to endure exile once again after the accession of Elizabeth and the establishment of the Protestant settlement.

Pole's rejection of the King's religious policy did not interrupt the scholarly intercourse between England and Padua. The tendency for Englishmen to use the studio as a "graduate" school continued, and these mature students still occasionally even relied on royal patronage to expedite their sojourns in the peninsula, although their financial support now came directly from the King without Pole's intermediary offices. These scholars, their learning polished and finished in Italy, returned, as had Pole's protégés, Starkey and Morison, to fill places at court in which they might employ their education and experience in the service of the state. The traditions of English scholarship in Italy were too established and the reputation of the University of Padua too exalted to be erased - or even significantly diminished - by the events of the Reformation and Pole's subsequent actions. Consequently, men such as Walter Buckler, John Caius, William Butts and Sir Thomas Smith, shared many of the experiences of Starkey and Morison except for their reliance on Pole's patronage.

The death of Henry VIII and the succession of his young son, Edward VI, did not change the tradition of English education in Padua. Nor did it alter the tendency for both Roman Catholic and Protestant scholars to study there. However, the lubricant of a royal pension was removed. The governments of Protector Somerset and Northumberland appeared not to have been willing to finance the education of promising English students abroad. Not only was money habitually scarce during these years, but also a relatively large pool of humanistically-trained bureaucrats and publicists already existed in England from which the Crown could summon sympathetic servants. Padua-educated humanists like Sir Richard Morison and Sir Thomas Smith achieved high office under Somerset or Northumberland, and others, such as William 
Thomas, whose History of Italy (1549) and Italian Grammar (1550) had made Italy so much more available to literate Englishmen, helped bring Italian influences close to the centre of power, a development that was simultaneously reinforced by Cranmer's patronage of Italian, often Padua-trained, reformers in the Edwardian Church. ${ }^{22}$

The cessation of royal patronage for study abroad, however, effected a change in the character of English students in Italy no less significant than that of Pole's household a generation before. Whereas Pole's patronage in Padua had tended to provide a means of support in Italy for brilliant, young scholars dedicated to lay careers, the collapse of official channels of patronage after 1547 altered the class composition of English students in Italy during the late 1540 's and 1550's. No longer did the members of the English natio at the university come mostly from the lesser gentry; now, they came from the greater gentry, the nobility or, during the Marian diaspora, even from the ranks of Edward VI's courtiers.

Furthermore, the educational purposes of these aristocratic students were clearly quite different both from their fifteenth-century clerical predecessors, who were destined for Church careers, and from the secular scholars of Pole's household, who used their Paduan learning to build careers in the Henrician bureaucracy and elevate their status. The gentlemen scholars of the middle years of the century did not intend to take degrees - often they did not even formally enrol as students - but rather they only audited lectures and experienced the social, cultural and intellectual environment of the university. A Paduan education, then, was no longer primarily a route to upward mobility, it was increasingly a perquisite of rank, a social cachet.

Thomas Hoby, the translator of Castiglione, is the best-documented English gentleman student in Italy during this period. He was the half-brother of Sir Philip Hoby, a successful ambassador and courtier of Henry VIII and Edward VI. Thomas Hoby left England in the summer of 1547 for an extended continental tour which ultimately led to Venice. ${ }^{23}$ While in the capital he lived at the house of Edmund Harvel $(1548)^{24}$ but soon moved to Padua where a number of Englishmen were already in residence. ${ }^{25}$ At the studio Hoby read Italian and humanities with the most celebrated professors of his day; and, indeed, this shift in interest from the professional study of medicine and law to the Arts university illustrates well the different intentions of such gentlemen scholars. ${ }^{26}$

Among the Englishmen in Padua in 1549 was Henry Killigrew, with whom Hoby travelled to Mantua. Killigrew was from a very prominent Cornish family and almost certainly was an Arts student at the studio. Under Elizabeth, Killigrew would rise to become the leading English diplomatist. ${ }^{27}$

In addition, while a student at Padua, Hoby met Sir Thomas Wyatt the Younger, the future rebel against Queen Mary. Wyatt's father, the celebrated Henrician poet of the same name, had stirred the Tudor court's interest in 
Italian verse forms through his translations and paraphrases of Petrarch's Canzoniere and Aretino's Penitential Psalms: indeed, Wyatt's version of Aretino marked the first direct translation of Italian literature into English since Chaucer. Obviously, the interests of the father continued in the son, hence the younger Wyatt's studies in Italy. ${ }^{28}$

Therefore, the place of Padua in the imagination of Englishmen was extremely complex by the accession of Mary I. The vitriolic propaganda of the Reformation had identified Rome with Babylon and the Pope with the AntiChrist. The Inquisitions established at Rome (1542) and at Venice (1547) seemed to substantiate the fear that heterodox beliefs would lead to the stake if pronounced in territories under their jurisdictions. Reginald Pole was believed to have betrayed his cousin the King and his nation, leading into opposition a number of other learned and pious young Englishmen - and he had made that decision in Italy and had remained there to work against the King's policies.

On the other hand, Venice had maintained close, sympathetic relations with England throughout the period of the Reformation. Padua, its university, did not require religious tests of its students and continued to admit Lutherans from Germany. Learning had reached its highest development in the studio, and the professors were the finest in Europe, and Venice herself protected the university's liberties and privileges against the Holy See, despite the events of the Reformation. The whole of the peninsula enjoyed a reputation for good manners and good letters, an opinion brought away by all visitors, including responsible Englishmen; and Italy had been the scene of antiquity's greatest period and the survival of its ruins provided a direct link with that past. Finally, Englishmen had been going to Italy since Pope Gregory associated angli with angeli. Any disruption of that ancient, traditional connection would have reduced a large part of the English experience to only vague memories.

Moreover, with a very few interruptions, that tradition had been continuous. The statement in the 1551 statutes of the Law University at Padua that there had not been any residents in the English nation for some years ${ }^{29}$ represented only a legalistic observation. It meant simply that no English student had registered as a legist with the rector, not that there were no Englishmen present in the city. For example, Thomas Hoby and Henry Killigrew among others were in Padua in 1549; one Englishman, Francis Southwell, was quite possibly an Arts student during 1551; and another, John Orphinstrange, a registered legist, must have arrived soon after. What the statement does indicate, however, is that Englishmen were journeying to Padua for different purposes. They were now often independent gentlemen who desired to acquire culture and learning in an environment free of the religious and political complications that existed at home. The benefits of enrolling as a student - exemption from customs' duties and freedom from the 
civic authorities ${ }^{30}$ - did not greatly concern them. They usually had no intention of taking a degree, desiring only to taste the opportunities open to them through the university and the good society of the city.

The displaced Protestant courtiers and servants of Edward VI who fled to Italy after the failure of the plots to exclude Mary from the throne belonged very much to this tradition. By 1553 , Venice and Padua were established places in their mental geographies. All the advantages of residence there would have been apparent to them and the prospects of such an experience far more attractive to these aristocratic, humanistic laymen than the other possible places of Protestant exile, like the burgher republics or petty principalities of Germany or Switzerland.

Such were the circumstances surrounding the arrival of the first English exiles in Italy under Queen Mary. On entering Padua, they encountered a substantial colony of English students and expatriates already present, linking the older tradition of English study in Padua and the more recent phenomenon of political or religious exile.

For example, when Francis Southwell or Thomas Cornwallis arrived in Italy is not known, but it is very probable that these two young gentlemen of prominent Roman Catholic families were sent abroad as an alternative to the new religious orientation of Edwardian Oxford and Cambridge. However, while in Italy, Southwell did not choose his associates only on the basis of religion; nor could he, since he shared a lodging with the strongly Protestant John Pelham, arranged by their common tutor. ${ }^{31}$ The accession of Mary soon brought Southwell and Cornwallis back to England where their families had risen to much authority. Their places were quickly taken by Protestant students who, perhaps like them, chose the religious and intellectual freedom of the studio over the contemporary religious policy of the English universities. To that extent, both the Catholic students under Edward and the Protestant students under Mary were effectively exiles for religion.

Except for Southwell, Cornwallis and, later, Edmund Wyndham, the Elizabethan legist, priest and recusant, ${ }^{32}$ all of the identifiable English students at Padua during the reign of Mary were Protestants. They came to Italy not only to expand their scholarly experience and knowledge, but also to circumvent the academic problems their religion occasioned. Nevertheless, although they shared this common characteristic, their individual motives and particular circumstances varied widely. For example, Francis Walsingham, destined to become Elizabeth's Puritan Principal Secretary, took advantage of the hostile religious climate at home to study in several places on the continent in order to observe the laws, customs, and governments of other states to better serve his own. ${ }^{33}$ His three cousins, the young sons of Sir Anthony Denny, appear rather to have been sent to Padua initially - perhaps in the company of their uncles, Roger and Matthew Carew and cousin Walsingham - to avoid religious contagion at Marian Oxford or Cambridge. In contrast, 
the journey to Italy of Edward Courtenay, Earl of Devon, another of Queen Mary's cousins, was not precipitated by principle but by necessity, ${ }^{34}$ and his enrolment as a legist at Padua was a public attempt to turn profit from his banishment. ${ }^{35}$ Similarly, Thomas Wilson fled abroad on the fall of his patron, Northumberland, in order to ensure his safety. He spent much time in Italy as a scholar, legal practitioner, conspirator and prisoner before he returned to his studies at Padua and Ferrara. (Under Elizabeth, Wilson would rise to become a Principal Secretary together with Walsingham.) John Pelham perhaps had been a student under Edward VI and thus not an exile for religion's sake. However, on leaving Padua, Pelham did not return to England; instead, he went to Geneva with his cousin and fellow student, William Morley, where both men joined the Marian exile community, entering the congregation of John Knox in November of $1557 .{ }^{36}$

Of all the Marian exiles on the continent, at least twenty-two definitely spent some time in studies in Padua. ${ }^{37}$ It is very possible that many others did so but either did not enrol with the rector or enrolled in the Arts Faculty at Padua and consequently no record of them survives. Matthew and Roger Carew, for instance, were almost certainly engaged in scholarship, perhaps privately or as tutors to their nephews. Similarly, John Tamworth, who would become a successful courtier of Elizabeth's, was very possibly a student, since he seems to have resided only in Padua and was the J.T. to whom William Thomas dedicated his Italian Grammar. Thomas Wilson stated that while in Padua he had read Greek with Sir John Cheke, former tutor to Edward VI and Secretary to Jane Grey, although he does not describe the nature of those studies of Demosthenes; nevertheless, it appears that Cheke did engage in some kind of scholarship at the studio during his residence in Venice. ${ }^{38}$

Padua, moreover, did hold more attractions than the university. The studio was the only recognized academy for the Venetian nobility. Therefore, the city was a centre of courtly, aristocratic culture as well as pure scholarship. Biagio Brugi has noted that "many students, especially foreigners, went to Padua to lead a pleasant life and to acquire the habits and manners of the Italians; and there they could learn the practice of arms, horsemanship, dances and music which had become the current fashion." 39 The taste for and already significant influence of Italian aristocratic culture on the English upper classes have already been observed. At Padua this transported, second-hand experience and knowledge acquired in England might be translated into a way of life. And what little is known about the recreational activities of the English community in Padua strongly supports the suggestion that a mixture of courtly graces and skills was indeed combined with serious study to reproduce the image of the ideal courtier described by Castiglione.

Francis Southwell's father and uncle, both sworn of Mary's Council, wrote officially to Peter Vannes, English envoy at Venice, enquiring about their relation's activities at Padua. Vannes replied to the Council on 5 January 
1554. He noted that "there is no nation in so great a number of strangers that do live more honestly than the English do" 40 and continued in a postscript, added after he had spoken to a scholar of Padua who knew Southwell, that the Englishman shared the same tutor, a Mr. Evered, ${ }^{41}$ with John Pelham and that both young men had lodged with a certain scholar of Greek and Latin while their tutor was in Rome. ${ }^{42}$ Southwell's area of study was the Latin and Italian languages and he was very well taught by his tutor. For his recreation, Southwell had for his companions other "worshipful gentlemen of England" and his "pastime [was playing] much upon the lute," even though he tended to be "too much studious than slack in learning." 43

Certainly Vannes wanted to present a good picture of the young man's activities, given Southwell's influential connections; but the portrait that emerges of the student's style of life is just what might be expected of a rich, young layman of good family, abroad for his education. For gentlemen seeking fashionable manners, a free environment, and a sound humanistic education, Padua was clearly perceived as the most attractive choice.

Therefore, the profile of English students at the university of Padua changed significantly throughout the first half of the sixteenth century. What had begun as a continuation of the Medieval tradition of study in Italy, largely by clerics, became, through the instrument of Pole's household in Padua during the 1520's and 1530's, a vehicle to secular careers in the Tudor court or bureaucracy. Subsequently, the religious toleration offered by the Venetian Republic, the increasing interest in Italian Renaissance styles and manners among the aristocracy, and the cessation of royal patronage of study abroad after the death of Henry VIII altered the class character of English students at the studio di Padova. Fewer "middle class" Englishmen were able to make the journey, and the availability of Italian courtly culture was somewhat irrelevant to such scholars anyway: tuition in true religion at a German or Swiss university was increasingly of more appeal to them than the aristocratic secular humanism of Padua. Consequently, when the need for a congenial place of exile arose during the Marian Reaction, the more extreme Protestants and those of lesser rank chose residence north of the Alps and east of the Rhine, while their better-born fellows, familiar with Italian aristocratic culture from the court, sought a period of study at Padua so that they might turn the bitterness of exile to some profit by acquiring those elements of social grace and intellectual polish that later were to provide the court of Elizabeth with its Italianate character. These inglesi italianati returned to England in 1558 to fill high offices and consequently sustained the identification of a Paduan education with a successful career.

Padua, then, was a central locus in the educated English imagination. It was a traditional vehicle for upward mobility, first in the Church and the universities, then in the state, and finally at court; it functioned as a primary channel for the transmission of Italian Renaissance values and styles into England; it 
served as a place of refuge from political and religious persecution. Despite the cataclysms of the Reformation and Pole's defection, Padua and its university retained their attraction for Englishmen and provided the necessary conditions for the development of a peculiarly English version of the Renaissance, in which Italian styles were domesticated by native tradition and genius.

\section{University of Toronto}

\section{Notes}

1 D.J. Geanakoplos, "The Discourse of Demetrius Chalcondyles on the Inauguration of Greek Studies at the University of Padua in 1463," Studies in the Renaissance, 21 (1974), 11.

2 Niccolò Leonico Tomeo (1452-1531) was one of the greatest scholars of the University of Padua. He had studied Greek with Chalcondyles in Florence before returning to Venice. The Signory appointed him professor of Greek and Philosophy in 1497. Besides his reputation as a scholar, he was known as an art collector and enough of a wit to merit mention by Castiglione in The Courtier. See Baldassare Castiglione, The Book of the Courtier, G. Bull, trans. (Harmondsworth: Penguin, 1967), 177.

3 See Roberto Weiss, Humanism in England During the Fifteenth Century (Oxford: Blackwell, 1957).

4 The great exception to this observation is William Sellyng, Prior of Christ Church, Canterbury. Sellyng was sent to study in Italy where he was a student of Angelo Poliziano and Chalcondyles. He learned Greek and returned to Canterbury to teach that language. As prior of his house (1472-95) he continued to support the teaching of Greek which he introduced to Christ Church. One of the pupils at that monastic school was Thomas Linacre. Six years later, Sellyng was sent by Henry VII to Rome as an ambassador to the pope and brought with him Thomas Linacre, who subsequently remained in Italy to study Greek further with Sellyng's old teacher, Chalcondyles. See Cardinal Gasquet, Cardinal Pole and His Early Friends (London: Bell, 1927), 3-6.

5 The University of Padua was familiarly called $i l B o$ because its original building had been an inn of that name (the steer).

6 L. Rosetti, L'Università di Padova: Profilo storico (Milan: Fabbri, 1972), 18. Also, Philip McNair, in his Peter Martyr in Italy (Oxford: Clarendon, 1967), 67, has noted that "there was hardly an Italian prominent in his country's frustrated Reformation who was not connected with the University of Padua." Indeed, the list is remarkable: Vermigli, Mariano Sozzini, Emmanuelle Tremelli, Francesco Porto, just to name a few.

7 Oaths of orthodoxy were not required of students before 1564 (and even then they were quite easily avoided). In 1547 the Republic established a state heresy tribunal, the tre savi sopra eresia; but, if the fabric of the state was not disturbed, private confessional opinions were tolerated, especially among foreigners.

8 Aldo Stella, "Utopie e velleità insurrezionali dei filoprotestanti italiani," Bibliothèque d' Humanisme et Renaissance, 27 (1965), 141.

9 See W.G. Zeeveld, Foundations of Tudor Policy (Cambridge, Mass.: Harvard, 1948).

10 J. Brewer, et al., eds., Letters and Papers, Foreign and Domestic, of the Reign of Henry VIII, (London: H.M.S.O., 1862-1932), VI, \#314.

11 There were in fact more than twenty-five professors of law and thirty of medicine at the University of Padua. See Biagio Brugi, Gli scolari dello studio di Padova nel cinquecento (Padova: Drucker, 1905), 29.

12 Zeeveld's masterful study is excellent for the reign of Henry VIII. However, he is mistaken in suggesting that the continued operation of Edmund Harvel's household in Venice sustained the English community there through the reign of Mary. Harvel in fact had died in 1550.

13 A number of Wolsey's protégés at Cardinal College had adopted Lutheranism. See Zeeveld, op. cit. Pole appears to have accepted such young men into his household in Padua. Pole himself was closely 
associated with the reforming party among the orthodox Roman Catholics, and, consequently, this confessional attitude should not be seen as too peculiar.

14 For a more detailed discussion of Starkey and his writings, see Zeeveld, op. cit., and S.J. Herrtage, ed., England in the Reign of Henry VIII (London: E.E.T.S., 1927).

15 S.T.C. 23236.

16 Thomas Starkey, A Dialogue Between Pole and Lupset, ed., K.M. Burton (London: Chatto and Windus, 1948).

17 I. Andrich, ed. De natione anglica et scota iuristarum universitatis patavinae (Padova, 1892), 130. It should be noted that Padua was divided into two Faculties: the Law University (with twenty-one nationes) and the Arts University (with seven nationes). Andrich records only the legists; the archives of the artists for this period are lost. Students must be identified from other sources.

18 Morison at least knew of Machiavelli and hence must have had some familiarity with contemporary Italian literature. See Calendar of State Papers, Foreign, Edward VI (Cal. For., Ed. VI), 213, 13 July 1552.

19 D.N.B. XXII, 97. One of the last Marian bishops (d. 1585), Goldwell of St. Asaph's was the only English bishop at the Council of Trent.

20 D.N.B. XI, 266. Cole, who became dean of St. Paul's, preached at Cranmer's execution.

21 In 1551 the Council ordered Vannes to watch English travellers in Italy, especially Roman Catholics. Cal. For., Ed. VI, \#'s 313, 354, 409.

22 Cranmer invited a number of Italian Protestant refugees to England, including Vermigli, Bernardino Ochino, Tremelli.

23 Thomas Hoby, A Book of the Travail and Lief of Me Thomas Hoby, ed. E. Powell (London: Camden Society, 1902).

24 Harvel was the unofficial English representative in Venice. He was not an ambassador, but a "nuncio" to the Venetians.

25 Hoby, op. cit., 8.

26 Hoby studied with Lazarus Bonamico (Leonico's successor), Mantuanus, Tumellus, Tomitano and Claudio Tolomei. See also, G. Parks, "The First Italianate Englishmen," Studies in the Renaissance 8 (1961), 207.

27 See A.C. Miller, Sir Henry Killigrew: Elizabethan Soldier and Diplomat (Leicester: Leicester U.P., 1963).

28 C. Garrett, The Marian Exiles (Cambridge: Cambridge U.P., 1938), 293-4.

29 Statuta ... Universitatis Iuristarum (Padua: 1555), fol. $3^{\mathrm{v}}-4^{\mathrm{r}}$.

30 Hoby, op. cit., 10-11.

31 B.M. Harley 5009 , fol. $78^{v}$.

32 Edmund Wyndham appears to have taken priests' orders in England under Mary. He travelled to Padua where he served as Consiliarius and Electionarius of the English nation after the resignation of Walsingham. Under Elizabeth, he refused the Oath of Supremacy and suffered imprisonment and exile. Wyndham was protected from more severe punishment by his powerful brother-in-law, Sir Nicholas Bacon.

33 See Conyers Read, Mr. Secretary Walsingham and the Policy of Queen Elizabeth (Oxford: Clarendon, 1925), I, 17.

34 Courtenay was very properly in fear of his life. See my article, "The Misfortune That Is Wished For Him: The Exile and Death of Edward Courtenay, Eighth Earl of Devon," Canadian Journal of History, 14 (1979), 1-28.

35 The fact that Courtenay registered at all was unusual; but the text of that registration indicates much of the young nobleman's pretensions. He signed himself, "nobilis anglus ex regia Albae Rosae britannorum familia."

36 Garrett, op. cit., 248.

37 For a complete discussion, see my unpublished University of Toronto Ph.D. thesis, The English Exile Community in Italy Under Queen Mary I (1553-1558). 1978. 


\section{8 / Renaissance and Reformation}

38 Demosthenes, Three Orations in Favour of the Olythians, trans. Thomas Wilson (London: 1570), dedicatory epistle, n.p.

39 B. Brugi, Gli scolari dello studio di Padova nel cinquecento (Padova, 1905), 38.

40 B.M. Harley 5009, fol. $78^{v}$.

41 This Mr. Evered might very well have been the King's Jeweller to Edward VI.

42 B.M. Harley 5009 , fol., $78^{\vee}$.

43 Ibid. 